\title{
Zastosowanie narzędzi programistycznych do oceny zapylenia w eksploatowanych wiertnicach
}

\begin{abstract}
Zapylenie jest to ogólnie przyjęta nazwa na określenie zawartości pyłu w powietrzu frakcji wdychalnej i/lub respirabilnej na stanowiskach pracy. Podstawę oceny narażenia w środowisku pracy stanowią najwyższe dopuszczalne stężenia pyłu (NDS). Artykuł obejmuje zagadnienie zapylenia, zasady pobierania zapylonego powietrza, wykonanie pomiaru oraz metody obliczania wartości wynikowych. Przeprowadzono pomiary zapylenia na stanowisku spawacza w pomieszczeniu spawalni. Opracowano arkusz kalkulacyjny służący do gromadzenia danych z wykonanych pomiarów i obliczeń wskaźników zapylenia na stanowiskach pracy. Uzyskane wyniki zostały wykorzystane do testowania zaimplementowanych w arkuszu kalkulacyjnym metod oceny szkodliwości zapylenia.
\end{abstract}

Słowa kluczowe: zapylenie, środowisko pracy, arkusz kalkulacyjny.

\section{Use of programing tools to evaluate dust concentration in drilling rig environment}

Personal dust is a generally accepted name for respirable dust content in the working environment. The exposure assessment is based on the highest allowable dust concentrations (NDS). This publication discusses the issue of dust problem, principles of sampling dust-laden air, performing the measurement and the method of result calculation. Measurements were performed at a welder's working place in a welding shop. Taking into account technical progress, a spreadsheet for data collection and calculation of respirable dust content in the working environment was prepared. Obtained results were used to test the methods implemented in this spreadsheet and were employed for assessing the harmfulness of dust.

Key words: dust, working place environment, spreadsheet.

\section{Wstęp}

Pył jest to zbiór cząstek stałych, które wyrzucone w powietrze utrzymują się w nim przez pewien czas. Najczęściej są to cząstki o wymiarach poniżej $300 \mu \mathrm{m}$. Aby określić rodzaj pyłu, należy wykonać badanie krystalicznej krzemionki. Z uwagi na różnorodny kształt cząstki pyły są pojęciem umownym i obejmują:

- pyły - cząstki stałe, powstające podczas mechanicznej obróbki materiałów, które unoszą się w powietrzu,

- dymy - np. pary metali podczas spawania, odlewania,

- mgły - krople o bardzo małych rozmiarach powstające z substancji ciekłych, np. podczas rozpylania.

Norma PN-ISO 7708:2001 podaje definicje frakcji pyłów stosowane do oceny zagrożenia zdrowia. Stężenie pyłu w środowisku pracy określone jest przez najwyższe dopuszczalne stężenie (NDS) średnie ważone, które działając na pracownika w ciągu 8-godzinnego czasu pracy, przez okres jego aktywności zawodowej nie powinno spowodować ujemnych zmian w jego stanie zdrowia oraz w stanie zdrowia jego przyszłych pokoleń. Najwyższe dopuszczalne stężenia określone rozporządzeniem uzależnione są od składu chemicznego i mineralnego pyłu oraz frakcji, a ponadto od zawartości w pyle wolnej krystalicznej krzemionki. Pracownik podczas wykonywania pracy zawodowej narażony jest na działanie różnych czynników (pył, hałas, substancje chemiczne), które często negatywnie działają na organizm. Prowadzi to do pogorszenia stanu zdrowia i samopoczucia pracowników, obniżenia wydajności pracy, zwiększenia liczby wypadków i powstawania chorób zawodowych. Pył przemysłowy jest występującym czynnikiem środowiskowym zanieczyszczeń powietrza na stanowiskach pracy w obiektach górnictwa nafty 
i gazu. Do pyłów przemysłowych zalicza się tylko te cząstki stałe, które w warunkach długotrwałego narażenia powodują zmiany w drogach oddechowych pracowników wykonujących różnorodne prace. W obiektach górnictwa naftowego prace związane ze zjawiskiem zapylenia wykonywane są zazwyczaj dorywczo, jako prace pomocnicze dotyczące prawidłowej eksploatacji obiektów naftowych. Ze względu na właściwości biologiczne - pyły przemysłowe dzielimy na: pyły o działaniu drażniącym (żelazo, szkło), pyły o działaniu zwłókniającym - są to krystaliczne formy dwutlenku krzemu $\left(\mathrm{S}_{\mathrm{i}} \mathrm{O}_{2}\right)$, jak kwarc oraz niektóre krzemiany, inne pyły mieszane, w których skład wchodzi krzemionka, pyły o działaniu uczulającym, rakotwórczym (azbest, drewno dębu), krystaliczna krzemionka. Czynnikami określającymi zagrożenie są: średnice cząstek pyłu występujące w strefie przebywania pracowników, zawartość wolnej krystalicznej krzemionki w pyle, wielkość narażenia (stężenie pyłu w środowisku pracy, czas narażenia), indywidualna wrażliwość.

\section{Zapylenie w środowisku pracy}

Pyły są jednym z głównych czynników szkodliwych występujących w środowisku pracy na wiertni. Zgodnie z kodeksem pracy na wszystkich stanowiskach pracy powinny być prowadzone działania zmierzające do skutecznego ograniczenia lub eliminowania ryzyka zawodowego wynikającego z narażenia na czynniki szkodliwe, w tym również na pyły. Głównymi źródłami emisji pyłów w pomieszczeniach pracy są procesy technologiczne. W zależności od rodzaju zastosowanego procesu technologicznego emitowane pyły charakteryzują się różnymi właściwościami. Do najbardziej pyłotwórczych procesów technologicznych należą: mielenie, kruszenie, przesiewanie i mieszanie ciał sypkich. Jednakże najwięcej pyłów wysokodyspersyjnych, najbardziej szkodliwych dla pracowników, powstaje w trakcie ostrzenia, szlifowania, spawania oraz polerowania. Podstawę zarówno do oceny ryzyka zawodowego, jak i do doboru środków ochrony zbiorowej i indywidualnej stanowią także podstawowe parametry pyłów, jak: stężenie, wymiary i kształt cząstek oraz skład chemiczny i struktura krystaliczna pyłów. Pyły zawierające krystaliczną krzemionkę oraz azbest są w kraju uznawane za pyły rakotwórcze. Do podstawowych odmian krzemionki należą: kwarc, krystobalit i trydymit. Rozpuszczalność w wodzie jest minimalna i uzależniona głównie od temperatury, $\mathrm{pH}$ roztworu, stopnia krystalizacji oraz wymiaru cząstek. Ostateczny skutek szkodliwego działania pyłów przemysłowych zależy także od ciężkości wykonywanej pracy fizycznej. Ocena narażenia na pyły polega na przeprowadzeniu pomiarów ich stężeń na stanowiskach pracy, określeniu wskaźników na pyły w odniesieniu do całodziennego czasu pracy i porównaniu uzyskanej wartości wskaźników ekspozycji z wartościami najwyższych dopuszczalnych stężeń pyłów (NDS-ów) [3]. Pracodawca, w którego zakładzie pracy występują szkodliwe dla zdrowia pyły, jest zobowiązany do dokonywania badań i pomiarów stężeń pyłów. W przypadku występowania szkodliwego dla zdrowia czynnika chemicznego lub pyłu, z wyjątkiem czynnika o działaniu rakotwórczym lub mutagennym, badania i pomiary wykonuje się:
- co najmniej raz na dwa lata, jeżeli podczas ostatniego badania stwierdzono stężenie czynnika szkodliwego dla zdrowia od powyżej 0,1 do 0,5 wartości najwyższego dopuszczalnego stężenia (NDS),

- co najmniej raz w roku, jeżeli podczas ostatniego badania i pomiaru stwierdzono stężenie czynnika szkodliwego dla zdrowia powyżej 0,5 wartości NDS.

W przypadku występowania czynnika o działaniu rakotwórczym lub mutagennym badania i pomiary wykonuje się:

- co najmniej raz na sześć miesięcy, jeżeli podczas ostatniego badania i pomiaru stwierdzono stężenie czynnika o działaniu rakotwórczym lub mutagennym od powyżej 0,1 do 0,5 wartości NDS,

- co najmniej raz na trzy miesiące, jeżeli podczas ostatniego badania i pomiaru stwierdzono czynnika o działaniu rakotwórczym lub mutagennym powyżej 0,5 wartości NDS,

- w przypadku narażenia na pył zawierający azbest - badania i pomiary wykonuje się co najmniej raz na trzy miesiące. Częstotliwość ta może być zmniejszona, jeżeli wyniki dwóch poprzednich pomiarów nie przekroczyły 0,5 wartości NDS, np. azbestu.

Do szacowania ryzyka zawodowego mogą być wykorzystywane różne metody i skale. Podczas szacowania ryzyka zawodowego jako kryterium odniesienia przyjęto wartości najwyższych dopuszczalnych stężeń pyłów (NDS):

$$
\begin{gathered}
\text { W }>\text { NDS }- \text { ryzyko duże } \\
\text { NDS } \geq \mathrm{W}>0,5 \mathrm{NDS} \text { - ryzyko średnie } \\
\mathrm{W} \leq 0,5 \mathrm{NDS}-\text { ryzyko małe }
\end{gathered}
$$

Dobór odpowiednich środków ochrony zbiorowej przed zapyleniem jest istotnym zagadnieniem. Środki te obejmują systemy wentylacji mechanicznej ogólnej oraz instalacje i urządzenia wentylacji mechanicznej wyposażone we właściwe układy filtracyjne. Do oczyszczania powietrza są stosowane różne układy filtracyjne, w zależności od wymaganego stopnia czystości powietrza doprowadzonego lub odprowadzonego z pomieszczeń przez systemy lub instalacje wentylacyjne. Szczególnie trudne jest ograniczenie zapylenia na 
niestacjonarnych stanowiskach pracy. Wynika to z ciągłego lub okresowego przemieszczania się źródeł zanieczyszczeń. Środkiem doraźnym, który nie zwalnia pracodawcy z szukania innych sposobów ograniczenia narażenia na pył, są środki ochrony indywidualnej. Stosowane maski przeciwpyłowe stanowią pewną uciążliwość w pracy i nie zawsze są chętnie noszone przez pracowników. Powinny być używane po wykorzystaniu innych sposobów zwalczania zapylenia. Wyniki oceny narażenia są podstawą oceny ryzyka zawodowego oraz doboru środków ochrony przed zapyleniem.

\section{Badania zapylenia w Zakładach Nafty i Gazu w ramach pracy statutowej 24/KA/16}

Pomiar zapylenia stanowiska spawacza wykonano w pomieszczeniu spawalni. Zastosowano dozymetrię indywidualną z wykorzystaniem pompki indywidualnej z próbnikiem (w naszym przypadku jest to aspirator indywidualny typu SKC 224-52TX według PN-91/Z-04030/05).

A. Przed pobraniem próbek powietrza ważymy sączki (typ sączka FIPR0-25).

$1-34,67 \mathrm{mg}$

$2-32,24 \mathrm{mg}$, masa sączków przed pobraniem pyłu $\left(m_{1}\right)$.

B. Ustalamy (przy pomocy rotametru) natężenie przepływu powietrza, z jakim pobierane będą próbki według PN-91/Z-04030/05 pkt 5b. W naszym przypadku jest to $2,01 / \mathrm{min}$.

C. Na stanowisku pracy pobieramy próbki powietrza za pomocą aspiratora indywidualnego typu SKC 224-52TX z odpowiednią głowicą pomiarową. Czas poboru próbki mierzymy legalizowanym stoperem.

$t_{1}=180 \mathrm{~min}-$ czas poboru pierwszej próbki,

$t_{2}=180 \mathrm{~min}-$ czas poboru drugiej próbki.

Po wykonaniu pomiarów przywozimy sączki z pobranym pyłem do laboratorium.

D. Ważymy sączki z pobranym pyłem.

$1-36,01 \mathrm{mg}$

$2-33,44 \mathrm{mg}$, masa sączków z pobranym pyłem $\left(m_{2}\right)$.

E. Obliczamy stężenie pyłu całkowitego w badanym powietrzu według wzoru:

$$
X=\frac{m_{2}-m_{1}}{v} \cdot 1000(\mathrm{PN}-91 / \mathrm{Z}-04030 / 05)
$$

gdzie:

$m_{2}$ - masa sączka po pobraniu próbki powietrza [mg],

$m_{1}$ - masa sączka przed pobraniem próbki powietrza [mg],

$v$ - objętość próbki powietrza obliczona jako iloczyn objęto-

ściowego natężenia przepływu pobieranego powietrza

i czasu pobierania (stężenie pyłu oznaczamy literą $\mathrm{C}$

- według PN-89/Z-04008/07).

$$
\begin{aligned}
& x_{1}=\frac{36,01-34,67}{2,0 \cdot 180 \mathrm{~min}} \cdot 1000=3,7 \mathrm{mg} / \mathrm{m}^{3}-C_{1} \\
& x_{2}=\frac{33,44-32,24}{2,0 \cdot 180 \mathrm{~min}} \cdot 1000=3,3 \mathrm{mg} / \mathrm{m}^{3}-C_{2}
\end{aligned}
$$

F. Obliczamy stężenie średnie ważone dla zmiany roboczej $C_{w}$ według wzoru 1 z PN-89/Z-04008/07.

$$
C_{w}=\frac{C_{1} \cdot t_{1}+C_{2} \cdot t_{2}+\cdots C_{n} \cdot t_{n}}{t_{1}+t_{2}+\cdots t_{n}}
$$

gdzie:

$C_{1}, C_{2}, C_{n}$ - stężenia otrzymane w wyniku oznaczania poszczególnych próbek $\left[\mathrm{mg} / \mathrm{m}^{3}\right]$,

$t_{1}, t_{2}, t_{n}$ - czas pobierania poszczególnych próbek [h],

$n$ - liczba próbek.

$$
C_{w}=\frac{3,7 \cdot 3+3,3 \cdot 3}{3+3}=3,5 \mathrm{mg} / \mathrm{m}^{3}
$$

G. Badamy zawartość wolnej krystalicznej krzemionki w pobranym pyle frakcji wdychalnej według PN-91/Z-04018/04 (w naszym przypadku $\mathrm{SiO}_{2}$ wynosi 2,63\%).

H. Dobieramy z tablicy Dziennika Ustaw Nr 79 z dnia 27 czerwca 1998 r. poz. 513 najwyższe dopuszczalne stężenie (NDS) dla badanego rodzaju pyłu. W naszym przypadku NDS $=4,0 \mathrm{mg} / \mathrm{m}^{3}$ (ponieważ zawartość krzemionki w pyle jest poniżej 50\%).

I. Obliczamy krotność, porównując stężenie średnie ważone dla zmiany roboczej $C_{w}$ z najwyższym dopuszczalnym stężeniem dla danego rodzaju pyłu. Dla pyłów zawierających wolną (krystaliczną) krzemionkę od 2\% do 50\% wartość NDS pyłu frakcji wdychalnej wynosi $4 \mathrm{mg} / \mathrm{m}^{3}$.

$$
\text { Krotność }=\frac{C_{w}}{N D S}=\frac{3,5}{4,0}=0,88
$$

Wyniki pomiarów zapylenia przedstawiono w tablicy 1 .

Z tablicy wynika, że frakcja wdychalna na stanowisku spawacza nie przekracza najwyższego dopuszczalnego stężenia dla danego pyłu. 
Tablica 1. Zapylenie frakcji wdychalnej na stanowisku spawacza

\begin{tabular}{|c|c|c|c|c|c|c|c|}
\hline \multirow{2}{*}{$\begin{array}{c}\text { Pomieszczenie } \\
\text { Stanowisko/strefa robocza } \\
\text { Opis czynności }\end{array}$} & \multirow{2}{*}{ Frakcja pyłu } & \multicolumn{2}{|c|}{$\begin{array}{c}\text { Stężenie pyłu } \\
{\left[\mathrm{mg} / \mathrm{m}^{3}\right]}\end{array}$} & \multirow{2}{*}{$\begin{array}{l}\text { Zawartość } \\
\qquad \mathrm{SiO}_{2} \\
{[\%]}\end{array}$} & \multirow{2}{*}{$\begin{array}{c}\text { NDS } \\
{\left[\mathrm{mg} / \mathrm{m}^{3}\right]}\end{array}$} & \multirow{2}{*}{$\begin{array}{c}\text { Krotność } \\
\text { [NDS] }\end{array}$} & \multirow{2}{*}{$\begin{array}{c}\text { Niepewność } \\
\mathrm{U}_{95} \\
{\left[\mathrm{mg} / \mathrm{m}^{3}\right]}\end{array}$} \\
\hline & & $\begin{array}{c}\text { oznaczenie } \\
C\end{array}$ & $\begin{array}{c}\text { średnia ważona } \\
C_{w}\end{array}$ & & & & \\
\hline Stanowisko spawacza & wdychalna & $\begin{array}{l}3,7 \\
3,3\end{array}$ & 3,5 & 2,63 & 4,0 & 0,88 & $\pm 0,3$ \\
\hline
\end{tabular}

Uwaga: tok obliczeń dla pyłu frakcji respirabilnej jest taki sam jak dla pyłu frakcji wdychalnej.

\section{Opracowanie arkusza kalkulacyjnego zapylenia}

W celu usprawnienia obliczeń związanych z obliczaniem parametrów oceny szkodliwości zapylenia na stanowiskach pracy opracowano arkusz kalkulacyjny. Arkusz pozwala w prosty i szybki sposób wyliczyć podstawowe parametry oceny zapylenia oraz oszacowania niepewności uzyskanych wyników. Wszystkie formuły zastosowane w algorytmach makra obliczeniowego arkusza są zgodne $\mathrm{z}$ aktualnie obowiązującymi normami: PN-Z-04008-7:2002, PN-91/Z-04030/05, PN-91/Z-04030/06, PN-ISO 4225:1999, PN-91/Z-04018/02, PN-91/Z-04018/03, PN-N-01341:2000/Ap1:2001, PN-ISO 1996-1:2006 i PN-ISO 1996-2:1999/A1:2002. Do pracy statutowej, na której podstawie powstał niniejszy artykuł, dołączono skoroszyt Zapylenie_KA_2016_A.xls, zawierający przykład obliczeniowy sporządzony z wykorzystaniem wykonanych pomiarów zapylenia $\mathrm{w}$ obiekcie pomiarowym opisanych w opracowaniu. Plik ten, wraz z przykładowym zestawem danych i wynikami obliczeń, dołączone są na krążku CD do niniejszego opracowania.

Przygotowany skoroszyt obejmuje następujące arkusze:

- „Opis” - zawiera dane zleceniodawcy, opis obiektu pomiarowego, wykonywanych czynności i użytej aparatury pomiarowej wraz z dokładnością przeprowadzanych pomiarów;

\section{Arkusz ,Opis”}

\begin{tabular}{|c|c|c|c|}
\hline \multicolumn{4}{|c|}{ DANE ZLECENIODAWCY I INFORMACJE O OBIEKCIE POMIAROWYM } \\
\hline Nazwa zleceniodawcy & \multicolumn{3}{|l|}{ Exalo Drilling S.A. Centrum Jasło } \\
\hline Adres & \multicolumn{3}{|l|}{ ul. Asnyka 6, 38-200 Jasło } \\
\hline \multicolumn{4}{|l|}{ Wydział } \\
\hline \multicolumn{4}{|l|}{ Lokalizacja } \\
\hline Nazwa obiektu pomiarowego & \multicolumn{3}{|l|}{ Spawalnia wiertnicy } \\
\hline Pomieszczenie - Stanowisko pracy & \multicolumn{3}{|l|}{ Stanowisko spawacza } \\
\hline Metoda przeprowadzenia pomiaru & \multicolumn{3}{|c|}{ dozymetria indywidualna z zastosowaniem pompki z próbnikiem } \\
\hline \multicolumn{4}{|c|}{ DANE O UŻYTEJ APARATURZE POMIAROWEJ } \\
\hline & & \multicolumn{2}{|c|}{ Dokładność } \\
\hline \multirow{5}{*}{ Użyta aparatura pomiarowa } & Aspirator indywidualny typu SKC 224-52TX & $5 \%$ & \\
\hline & Sączki FIPRO-25 & & \\
\hline & Rotametr typu Gilibrator 2 & 1 & {$[\mathrm{ml} / \mathrm{min}]$} \\
\hline & Waga laboratoryjna typu XA 60/220 & 0,02 & [mg] \\
\hline & Zegar & 1 & [min] \\
\hline
\end{tabular}

- „Pomiar” - w górnej części arkusza znajdują się dane: Rodzaj pyłu, Liczba pobranych próbek dla pyłu frakcji wdychalnej i respirabilnej, Dzienny czas ekspozycji na zapylenia, Temperatura otoczenia, Ciśnienie atmosferyczne, Minimalna masa próbki. W tabeli poniżej znajdują się wyniki pomiarów wykonane na próbkach dla oznaczenia pyłu frakcji wdychalnej i respirabilnej. Pole Rodzaj pylu wypełniane jest poprzez zaznaczenie odpowiedniej pozycji, cyfrą 1, w kolumnie Wybór rodzaju pyłu dla pomiaru $\mathrm{w}$ arkuszu NDS;

- „Wyniki” - zawiera tablicę z wyliczonymi wartościami dla pobranych próbek: masa próbki, stężenie pyłu frakcji wdychalnej oraz z wyliczonymi wartościami reprezentatywnymi dla zapylenia na stanowisku pracy: średnie stężenie pyłu, współczynnik NDS, krotność przekroczenia wskaźnika NDS w stosunku do wartości dopuszczalnych i niepewność całkowita oznaczenia średnich stężeń zapylenia;

- „NDS” - dodatkowy arkusz zawierający tablicę z listą czynników szkodliwych i odpowiadającymi im dopuszczalnymi wartościami stężeń.

Wszystkie formuły obliczeniowe wykonywane są za pomocą procedur zaimplementowanych w makrze o nazwie „Licz”. Makro to uruchamiane jest poprzez wybranie z klawiatury kombinacji klawiszy: $\mathrm{Ctrl}+\mathrm{x}$. Co do kolorystyki arkuszy przyjęto następującą zasadę:

- tło komórek zawierających opisy oznaczono kolorem jasnoniebieskim lub zielonym, a litery - granatowym lub brązowym,

- tło komórek zawierających opisy i dane pomiarowe oznaczono kolorem żółtym lub niebieskim, a litery - granatowym lub brązowym,

- tło komórek zawierających wyniki obliczeń oznaczono kolorem jasnoniebieskim, a litry - kolorem czerwonym.

Skany arkuszy dla przykładu obliczeniowego zamieszczono poniżej. 
Arkusz ,Pomiar"

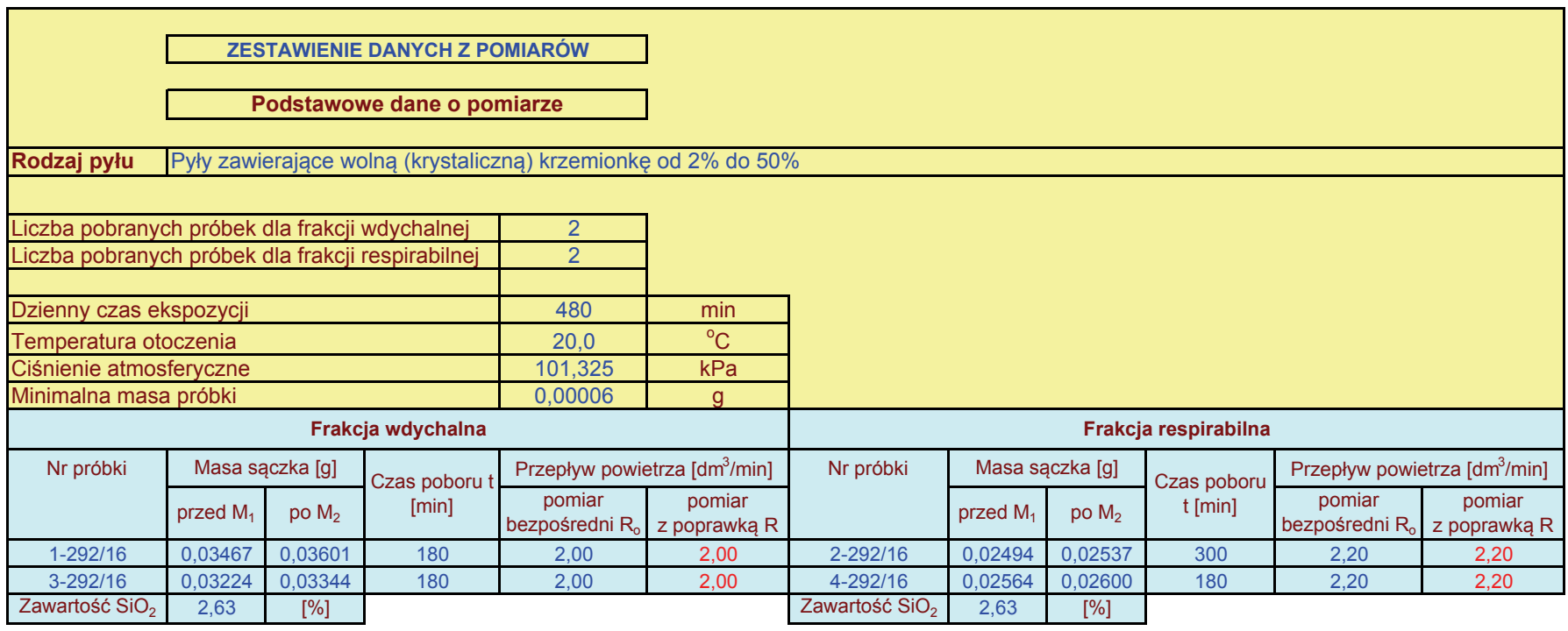

\section{Arkusz „Wyniki”}

\begin{tabular}{|c|c|c|c|c|c|}
\hline & \multicolumn{5}{|c|}{ INTERPRETACJA WYNIKÓW POMIARÓW } \\
\hline \multicolumn{3}{|c|}{ Frakcja wdychalna } & \multicolumn{3}{|c|}{ Frakcja respirabilna } \\
\hline Nr próbki & $\begin{array}{c}\text { Masa próbki } m \\
\text { [g] }\end{array}$ & $\begin{array}{c}\text { Stężenie } C \\
{\left[\mathrm{mg} / \mathrm{m}^{3}\right]}\end{array}$ & Nr próbki & $\begin{array}{c}\text { Masa próbki } m \\
{[\mathrm{~g}]}\end{array}$ & $\begin{array}{c}\text { Stężenie } C \\
{\left[\mathrm{mg} / \mathrm{m}^{3}\right]}\end{array}$ \\
\hline $1-292 / 16$ & 0,00134 & 3,72 & $2-292 / 16$ & 0,00043 & 0,65 \\
\hline $3-292 / 16$ & 0,00120 & 3,33 & $4-292 / 16$ & 0,00036 & 0,91 \\
\hline Frakcja pyłu & $\begin{array}{c}\text { Średnie } \\
\text { stężenie } C_{w} \\
{\left[\mathrm{mg} / \mathrm{m}^{3}\right]}\end{array}$ & $\begin{array}{c}\text { Zawartość } \\
\mathrm{SiO}_{2}[\%]\end{array}$ & $\begin{array}{c}\text { NDS } \\
{\left[\mathrm{mg} / \mathrm{m}^{3}\right]}\end{array}$ & Krotność NDS & Niepweność \\
\hline Frakcja wdychalna & 3,53 & 2,63 & 4 & 0,88 & 0,30 \\
\hline Frakcja respiarbilna & 0,75 & 2,63 & 1 & 0,75 & 0,12 \\
\hline
\end{tabular}

\section{Arkusz ,NDS"}

\begin{tabular}{|c|c|c|c|c|c|c|}
\hline \multicolumn{3}{|c|}{ Nazwa i numer CAS czynnika szkodliwego dla zdrowia } & \multirow{2}{*}{$\begin{array}{c}\text { Wybór } \\
\text { rodzaju } \\
\text { pyłu dla } \\
\text { pomiaru (1) }\end{array}$} & \multicolumn{3}{|c|}{ Najwyższe dopuszczalne stężenie } \\
\hline Lp. & $\mathrm{NrCAS}$ & Nazwa & & $\begin{array}{l}\mathrm{mg} / \mathrm{m}^{3} \\
\text { pył cał. } \\
{[1]}\end{array}$ & $\begin{array}{l}\mathrm{mg} / \mathrm{m}^{3} \\
\text { pył resp. } \\
{[2]}\end{array}$ & $\begin{array}{l}\mathrm{cm}^{3} \\
\text { wł resp. } \\
\text { [3] }\end{array}$ \\
\hline 1 & $14808-60-7$ 14464-46-1 15468-32-3 & $\begin{array}{l}\text { Pyły zawierające wolną (krystaliczną) krzemionkę } \\
\text { powyżej } 50 \%\end{array}$ & & 2,0 & 0,3 & \\
\hline 2 & $14808-60-7$ 14464-46-1 15468-32-3 & $\begin{array}{l}\text { Pyły zawierające wolną (krystaliczną) krzemionkę } \\
\text { od } 2 \% \text { do } 50 \%\end{array}$ & 1,0 & 4,0 & 1,0 & \\
\hline 3 & $1332-21-4$ & $\begin{array}{l}\text { Pyły zawierające azbest: (jeden lub więcej rodzajów azbestu: } \\
\text { aktynolit; antofilit; chryzotyl; grueneryt; krokidolit; termolit) }\end{array}$ & & 0,5 & - & 0,1 \\
\hline 4 & & & & & & \\
\hline 5 & $7782-42-57440-44-0$ & Pyły grafitu naturalnego & & 4,0 & 1,0 & \\
\hline 6 & $7782-42-5$ 7440-44-0 & Pyły grafitu syntetycznego & & 6,0 & & \\
\hline 7 & & $\begin{array}{l}\text { Inne nietrujące pyły przemysłowe - w tym zawierające wol- } \\
\text { ną (krystaliczną) krzemionkę poniżej } 2 \%\end{array}$ & & 10,0 & & \\
\hline 8 & & $\begin{array}{l}\text { Pyły organiczne pochodzenia zwierzęcego } \\
\text { i roślinnego zawierające } 10 \% \text { lub więcej wolnej krzemionki }\end{array}$ & & 2,0 & 1,0 & \\
\hline 9 & & $\begin{array}{l}\text { Pyły organiczne pochodzenia zwierzęcego } \\
\text { i roślinnego zawierające poniżej } 10 \% \text { wolnej krzemionki }\end{array}$ & & 4,0 & 2,0 & \\
\hline 10 & $14807-96-6$ & $\begin{array}{l}\text { Pyły talku i talku zawierającego włókna mineralne (w tym } \\
\text { azbest) talk niezawierający włókien mineralnych (w tym } \\
\text { azbestu) }\end{array}$ & & 4,0 & 1,0 & \\
\hline
\end{tabular}


cd. Arkusza ,NDS"

\begin{tabular}{|c|c|c|c|c|c|c|}
\hline \multicolumn{3}{|c|}{ Nazwa i numer CAS czynnika szkodliwego dla zdrowia } & \multirow{2}{*}{$\begin{array}{c}\text { Wybór } \\
\text { rodzaju } \\
\text { pyłu dla } \\
\text { pomiaru (1) }\end{array}$} & \multicolumn{3}{|c|}{ Najwyższe dopuszczalne stężenie } \\
\hline Lp. & $\mathrm{Nr}$ CAS & Nazwa & & $\begin{array}{c}\mathrm{mg} / \mathrm{m}^{3} \\
\text { pył cał. } \\
{[1]}\end{array}$ & $\begin{array}{c}\mathrm{mg} / \mathrm{m}^{3} \\
\text { pył resp. } \\
{[2]}\end{array}$ & $\begin{array}{c}\mathrm{cm}^{3} \\
\text { wł resp. } \\
{[3]}\end{array}$ \\
\hline 11 & $14807-96-6$ & $\begin{array}{l}\text { Pyły talku i talku zawierającego włókna mineralne (w tym } \\
\text { azbest) talk zawierający włókna mineralne (w tym azbest) }\end{array}$ & & 1,0 & & 0,5 \\
\hline 12 & & $\begin{array}{l}\text { Pyły sztucznych włókien mineralnych, } \\
\text { z wyjątkiem włókien ceramicznych }\end{array}$ & & 2,0 & & 1,0 \\
\hline 13 & & Pyły sztucznych włókien pyły włókien ceramicznych & & 1,0 & & 0,5 \\
\hline 14 & & $\begin{array}{l}\text { Pyły włókien ceramicznych w mieszaninie } \\
\text { z innymi sztucznymi włóknami mineralnymi }\end{array}$ & & 1,0 & & 0,5 \\
\hline 15 & $65997-15-1$ & Pyły cementów portlandzkiego i hutniczego & & 6,0 & 2,0 & \\
\hline 16 & & $\begin{array}{l}\text { Pyły apatytów i fosforytów zawierające wolną krystaliczną } \\
\text { krzemionkę poniżej } 2 \%\end{array}$ & & 6,0 & 2,0 & \\
\hline 17 & & $\begin{array}{l}\text { Pyły apatytów i fosforytów zawierające wolną krystaliczną } \\
\text { krzemionkę powyżej } 2 \%\end{array}$ & & 4,0 & 1,0 & \\
\hline 18 & $1333-86-4$ & Pyły sadzy technicznej & & 4,0 & & \\
\hline 19 & & $\begin{array}{l}\text { Pyły węgla kamiennego i brunatnego zawierające wolną kry- } \\
\text { staliczną krzemionkę powyżej } 50 \%\end{array}$ & & 1,0 & 0,3 & \\
\hline 20 & & $\begin{array}{l}\text { Pyły węgla kamiennego i brunatnego zawierające wolną kry- } \\
\text { staliczną krzemionkę powyżej } 10 \% \text { do } 50 \%\end{array}$ & & 2,0 & 1,0 & \\
\hline 21 & & $\begin{array}{l}\text { Pyły węgla kamiennego i brunatnego zawierające wolną kry- } \\
\text { staliczną krzemionkę od } 2 \% \text { do } 10 \%\end{array}$ & & 4,0 & 2,0 & \\
\hline 22 & & $\begin{array}{l}\text { Pyły węgla kamiennego i brunatnego zawierające wolną kry- } \\
\text { staliczną krzemionkę poniżej } 2 \%\end{array}$ & & 10,0 & & \\
\hline 23 & & $\begin{array}{l}\text { Pyły drewna, z wyjątkiem pyłów drewna twardego, takiego } \\
\text { jak buk i dąb }\end{array}$ & & 4,0 & & \\
\hline 24 & & Pyły drewna twardego, takiego jak buk i dąb & & 2,0 & & \\
\hline 25 & & $\begin{array}{l}\text { Pyły drewna mieszane zawierające pył drewna twardego, ta- } \\
\text { kiego jak buk i dąb }\end{array}$ & & 2,0 & & \\
\hline 26 & $61790-53-2$ & $\begin{array}{l}\text { Pyły krzemionek bezpostaciowych i syntetycznych ziemia } \\
\text { okrzemkowa (diatomit) niekalcynowana }\end{array}$ & & 10,0 & 2,0 & \\
\hline 27 & $68855-54-9$ & $\begin{array}{l}\text { Pyły krzemionek bezpostaciowych i syntetycznych ziemia } \\
\text { okrzemkowa (diatomit) kalcynowana[5] }\end{array}$ & & 2,0 & 1,0 & \\
\hline 28 & $112926-00-8$ & $\begin{array}{l}\text { Pyły krzemionek bezpostaciowych i syntetycznych krze- } \\
\text { mionka bezpostaciowa syntetyczna (strącona i żel) }\end{array}$ & & 10,0 & 2,0 & \\
\hline 29 & $60676-86-0$ & $\begin{array}{l}\text { Pyły krzemionek bezpostaciowych i syntetycznych krze- } \\
\text { mionka stopiona (szkło kwarcowe) }\end{array}$ & & 2,0 & 1,0 & \\
\hline 30 & $409-20-2$ & $\begin{array}{l}\text { Pyły węglika krzemu niewłóknistego o zawartości wolnej } \\
\text { krystalicznej krzemionki poniżej } 2 \%\end{array}$ & & 10,0 & & \\
\hline 31 & $7778-18-9$ & $\begin{array}{l}\text { Pyły gipsu zawierające wolną krystaliczną krzemionkę po- } \\
\text { niżej 2\% i niezawierające azbestu }\end{array}$ & & 10,0 & & \\
\hline 32 & & $\begin{array}{l}\text { Pyły dolomitu zawierające wolną krystaliczną krzemionkę } \\
\text { poniżej } 2 \% \text { i niezawierające azbestu }\end{array}$ & & 10,0 & & \\
\hline 33 & $1332-58-7$ & $\begin{array}{l}\text { Pyły kaolinu zawierające wolną krystaliczną krzemionkę } \\
\text { poniżej } 2 \% \text { i niezawierające azbestu }\end{array}$ & & 10,0 & & \\
\hline 34 & $13463-67-7$ & $\begin{array}{l}\text { Pyły ditlenku tytanu zawierające wolną krystaliczną krze- } \\
\text { mionkę poniżej } 2 \% \text { i niezawierające azbestu }\end{array}$ & & 10,0 & & \\
\hline 35 & & Węglan wapnia - pyły & & 10,0 & & \\
\hline 36 & & Spaliny silnika Diesla & & 0,5 & & \\
\hline 37 & & Pyły zawierające azbest & & 0,5 & & 0,1 \\
\hline
\end{tabular}




\section{Wyniki i uwagi końcowe}

1. Praca ma charakter stosowany i jest na bieżąco użytkowana przy ocenach zapylenia w zakładach przemysłu naftowego.

2. Jakość wykonywanych pomiarów na obiektach naftowych oraz branż pokrewnych ma decydujące znaczenie w dalszej analizie zagrożeń zapyleniem w miejscach przebywania pracowników.

3. Opracowany arkusz kalkulacyjny pozwala w stosunkowo krótkim czasie dokonać oceny wyników badań zapylenia w środowisku i na stanowiskach pracy.

4. Arkusz kalkulacyjny spełnia wymagania europejskie oraz obowiązujące rozporządzenia w tym zakresie.

Prosimy cytować jako: Nafta-Gaz 2017, nr 3, s. 193-199, DOI: 10.18668/NG.2017.03.07

Artykuł nadesłano do Redakcji 1.12.2016 r. Zatwierdzono do druku 20.01.2017 r.

Artykuł powstał na podstawie pracy statutowej pt. Badania zapylenia w Zakładach Nafty i Gazu zgodnie z wymaganiami Unii Europejskiej - praca INiG - PIB na zlecenie MNiSW; nr zlecenia 24/KA/16, nr archiwalny: DK-4100-24/16.

\section{Literatura}

[1] Augustyńska D., Pośniak M. (red.): Czynniki szkodliwe w środowisku pracy-wartości dopuszczalne. CIOP, Warszawa 2003.

[2] Balawajder Z., Buczek J.: Pomiary zapylenia na stanowiskach pracy. Dokumentacja INiG - PIB, Kraków 2014-2015.

[3] Dobrzelecka I.: Zasady pomiarów stężeń pyłów przemystowych. Interpretacja i ocena wyników. Materiały szkoleniowe, Sosnowiec 2000.

[4] Maciejewska A., Więcek E., Wojtczak J., Woźniak H., Sztroszejn-Mrowca G., Domańska A., Belichowska-Cybula G.: Pyty drewna. Podstawy i Metody Oceny Środowiska Pracy 1997, z. 15, s. 149-196.

[5] Urba R.: Niepewność pomiaru fizykomechanicznych czynników środowiskowych w zakładach górnictwa nafty i gazu. Nafta-Gaz 2010, nr 7, s. 573-576.

[6] Urba R., Kwilosz T.: Metodyka pomiarowo-interpretacyjna wyników badań mikroklimatu i zapylenia, jako czynników środowiska w zakładach górnictwa nafty i gazu. Nafta-Gaz 2010, nr 12, s. 1156-1161.

\section{Akty prawne i normatywne}

[7] Centralny Instytut Ochrony Pracy, http://www.ciop.pl (dostęp: wrzesień 2013).

[8] Dyrektywa 2002/49/WE z dnia 25 czerwca 2002 r. odnosząca się do oceny i zarządzania poziomem hałasu w środowisku.

[9] Główny Urząd Miar: Wyrażanie niepewności pomiaru. Przewodnik. Warszawa 1999.

[10] Norma PN-91/Z-04018/02 Ochrona czystości powietrza. Badania zawartości wolnej krystalicznej krzemionki. Oznaczanie wolnej krystalicznej krzemionki w pyle catkowitym na stanowiskach pracy metoda spektrofotometrii absorpcyjnej w podczerwieni.

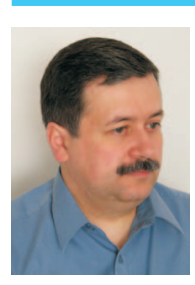

Dr Tadeusz KWILOSZ

Adiunkt w Zakładzie Podziemnego Magazynowania Gazu.

Instytut Nafty i Gazu - Państwowy Instytut Badawczy ul. Lubicz 25 A

31-503 Kraków

E-mail: tadeusz.kwilosz@inig.pl
[11] Norma PN-91/Z-04018/03 Ochrona czystości powietrza. Badania zawartości wolnej krystalicznej krzemionki. Oznaczanie wolnej krystalicznej krzemionki w pyle respirabilnym na stanowiskach pracy metoda spektrofotometrii absorpcyjnej w podczerwieni.

[12] Norma PN-91/Z-04018/04 Ochrona czystości powietrza. Badania zawartości wolnej krystalicznej krzemionki. Oznaczanie wolnej krystalicznej krzemionki w pyle calkowitym i respirabilnym w obecności krzemianów na stanowiskach pracy metoda kolorymetryczna.

[13] Norma PN-91/Z-04030/05 Ochrona czystości powietrza. Badania zawartości pytu. Oznaczanie pyłu calkowitego na stanowiskach pracy metoda filtracyjno-wagowa.

[14] Norma PN-91/Z-04030/06 Ochrona czystości powietrza. Badania zawartości pytu. Oznaczanie pyłu respirabilnego na stanowiskach pracy metoda filtracyjno-wagowa.

[15] Norma PN-ISO 4225:1999 Jakość powietrza. Zagadnienia ogólne. Terminologia.

[16] Norma PN-N-18001:2004 Systemy zarzadzania bezpieczeństwem i higiena pracy. Wymagania.

[17] Norma PN-Z-04008-7:2002/Az1:2004 Ochrona czystości powietrza. Pobieranie próbek. Zasady pobierania próbek powietrza $w$ środowisku pracy i interpretacji wyników.

[18] Rozporządzenie Ministra Pracy i Polityki Społecznej z dnia 6 czerwca 2014 r. w sprawie najwyższych dopuszczalnych stężeń i natężeń czynników szkodliwych dla zdrowia w środowisku pracy (Dz.U. poz. 817).

[19] Rozporządzenie Ministra Zdrowia z dnia 2 lutego 2011 r. w sprawie badań i pomiarów czynników szkodliwych dla zdrowia w środowisku pracy (Dz.U. Nr 33, poz. 166).

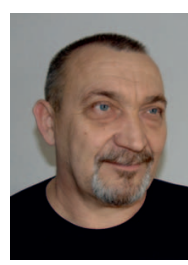

Janusz BUCZEK

Kierownik Laboratorium Badań Środowiskowych

Instytut Nafty i Gazu - Państwowy Instytut Badawczy

ul. Lubicz 25 A

31-503 Kraków

E-mail: janusz.buczek@inig.pl 